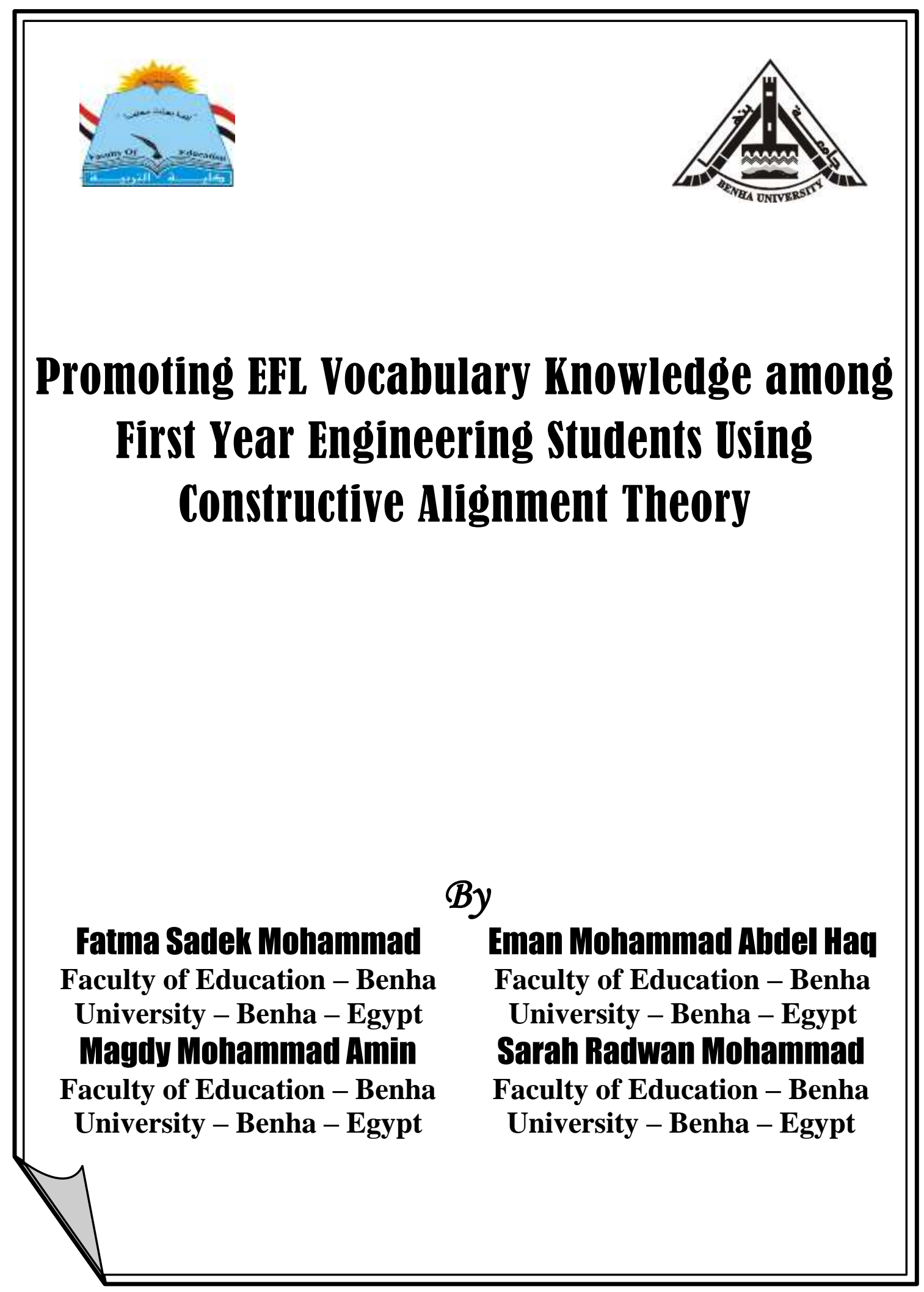




\section{Promoting EFL Vocabulary Knowledge among First Year Engineering Students Using Constructive Alignment Theory}

By

Fatma Sadek Mohammad

Faculty of Education

Benha University - Benha - Egypt

Magdy Mohammad Amin

Faculty of Education

Benha University - Benha - Egypt
Eman Mohammad Abdel Haq

Faculty of Education - Benha

University - Benha - Egypt

Sarah Radwan Mohammad Zakarya

Faculty of Education - Benha

University - Benha - Egypt

\section{Abstract}

Vocabulary knowledge plays an imperative role in developing students' language learning. This paper aimed at investigating the role of Constructive Alignment Theory in promoting vocabulary knowledge among Engineering students. Sixty three first year students at Benha Faculty of Engineering were randomly assigned into two groups: experimental group $(n=33)$ and control group $(n=30)$. Two main instruments were used: academic vocabulary pre-test, and academic vocabulary post-test. Quantitative data analyses were conducted. Results showed that the experimental group students have developed their vocabulary knowledge. It was concluded that the "Constructive Alignment Theory" was effective in promoting vocabulary knowledge of the participants. It was also recommended that the constructive alignment theory is effective in developing language learning in general as it helps students to be aware of their learning strategies and to be responsible of their own learning and in developing vocabulary knowledge in particular. Constructive Alignment Theory should be integrated into vocabulary learning programs.

Keywords: Constructive Alignment, and Vocabulary Knowledge. 


\section{Introduction:}

Vocabulary knowledge is the key element in developing all four language skills. This is especially relevant in English for Specific Purposes (ESP), occupational or academic, as one of the key differentiators from the so-called "general English" is the specialised vocabulary element. Building vocabulary is a highly demanding process in language learning. It is like building blocks in the language. Hence, vocabulary knowledge is important for ESP students because they need sufficient knowledge of the words before they can comprehend their academic subjects or what they have read. Vocabulary acquisition is the relation between knowing and understanding the meaning of words in the listening or reading processes to reuse it in their own speaking or writing.

Vocabulary knowledge is the key element in developing all four language skills. This is especially relevant in English for Specific Purposes (ESP), occupational or academic, as one of the key differentiators from the so-called "general English" is the specialised vocabulary element. Most researchers agree that a change is needed in the teaching environment, that vocabulary should gain a prominent role in the course syllabus and that specific teaching, learning and assessment methods should be implemented to help learners in vocabulary acquisition. Constructive alignment is an outcomes-based teaching and learning approach, and it can be applied to teaching and learning vocabulary regardless of what kind of vocabulary knowledge is trying to be achieved (receptive/productive; size/in-depth). (Pokupec \& Njerš, 2014, 1)

The present study intends to develop vocabulary knowledge among the study subjects through using constructive alignment. 


\section{Review of Literature and Related Studies}

When the learner constructs his or her own learning through relevant learning activities, it is called constructive alignment. The constructivist learning theory acted as a source for the development of student-centered approaches which are ways of thinking about teaching and learning that emphasize student responsibility and activity in learning rather than content or what the teachers are doing.

Biggs $(2003,2)$ indicated that constructive alignment has two aspects. The constructive aspect refers to the idea that students construct meaning through relevant learning activities; that meaning is not something imparted or transmitted from teacher to learner, but is something learners have to create for themselves. Teaching is simply a catalyst for learning. The alignment aspect refers to what the teacher does, which is to set up a learning environment that supports the learning activities appropriate to achieving the desired learning outcomes. The key is that the components in the teaching system, especially the teaching methods used and assessment tasks are aligned with the learning activities assumed in the intended outcomes. The learner is in a sense 'trapped', and finds it difficult to escape without learning what he or she is intended to learn.

According to Biggs $(2003,2)$ and Surgenor $(2010,1)$, the bases in alignment process are: A) defining the intended learning outcomes. B) Choosing teaching and learning activities likely to lead to help and encourage students to attain these objectives assessing students' learning outcomes using methods that enable students to demonstrate the intended 
learning and evaluating how well they match what was intended. C) Arriving at a final grade, and perhaps in the case of formative assessment, giving feedback to help students improve their learning

Simultaneously, the SOLO taxonomy, which stands for the Structure of the Observed Learning Outcome, helps to map levels of understanding built into the intended learning outcomes. According to Biggs (1996, 351), SOLO provides a systematic way of describing how a learner's performance grows in complexity when mastering many academic tasks. Five levels may be distinguished. The first is prestructural, the task is not attacked appropriately; the student hasn't understood the point. In the unistructural level, one or few aspects of the task are picked up and used (understanding as nominal). While in the multistructural, several aspects of the task are learned but are treated separately (understanding as knowing about). In the relational level, the components are integrated into a coherent whole, with each part contributing to the overall meaning (understanding as appreciating relationships). While in the extended abstract, the integrated whole at the relational level is reconceptualised at a higher level of abstraction which enables generalization to a new topic or area, or is turned reflexively on oneself (Understanding as involving metacognition).

According to Jones $(2002,6)$, Biggs identified 3P model which provides a useful context for understanding the importance of approaches to learning. The model suggests the students' personal characteristics and the situation they are in influences the learning approach they adopt which in turn affects the outcomes they achieve from their learning" as in the following figure: 


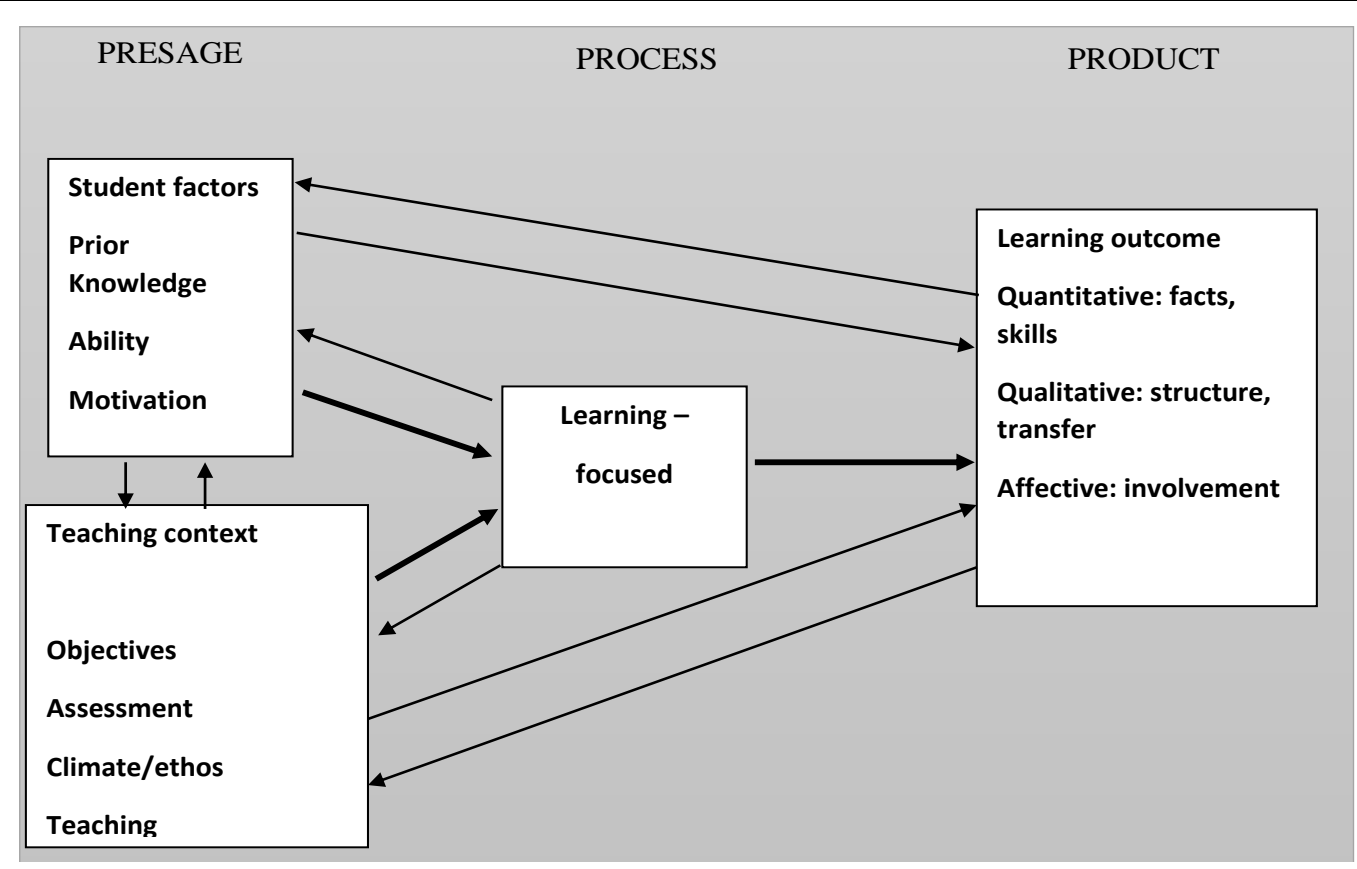

Figure (1): Systems model of study processes (Jones, 2002, 8)

Figure (1). Adapted from "Biggs's 3P Model of Learning: The Role of Personal Characteristics and Environmental Influences on Approaches to Learning" by Jones, Catherine, 2002, Unpublished Ph.D. thesis, Faculty of Health Science, Griffith University, Australia.

Language teachers should not stop from reinventing their methods and pedagogical strategies. It is also advisable if they can find time reviewing all their Intended Learning Outcomes in a certain course and align them with their Teaching - Learning Activities and assessment. They can also utilize constructive alignment in knowing students' problems and finding solutions to these for improvement and professional growth. They can encourage students to choose their own way, style, or even preferences and the appropriate strategies to achieve their objectives in their language learning. (Chua, 2013, 244).

On the other hand, vocabulary knowledge is the relation between knowing and understanding the meaning of words in listening or reading processes to reuse it in speaking or writing. Mebring $(2005,3)$ stated that 
students can retain the vocabulary they find useful and relevant to their subject matter by learning vocabulary through context, cooperative learning, and using technology.

Acoording to Rasouli and Jafari (2016, 42-43), "there are four tasks for vocabulary learning: Repetition: atypical learner should meet a word about 8 to 10 times to obtain full word knowledge; Focus on meaning and form; Engagement: which means that the learners reflect on words and their use, and they have the ability to analyze the words; and Interaction and negotiation: word learning is a consequence of exposure.

\begin{tabular}{|c|c|}
\hline From & To \\
\hline $\begin{array}{l}\text { Approaching vocabulary instruction as } \\
\text { a stand-alone strategy }\end{array}$ & $\begin{array}{l}\text { Organizing vocabulary instruction within } \\
\text { content-based unit of study that involves } \\
\text { reading, writing, and dialogue. }\end{array}$ \\
\hline Stating with long lists of words & $\begin{array}{l}\text { Selecting a small set of useful and complex } \\
\text { words for study, and complementing this } \\
\text { instruction with a focus on word leaming } \\
\text { strategies }\end{array}$ \\
\hline $\begin{array}{l}\text { Teaching word through a series of } \\
\text { memorization and spelling activities } \\
\text { and independent worksheets }\end{array}$ & $\begin{array}{l}\text { Studying words and concepts using multiple } \\
\text { methods and formats, including lots of } \\
\text { collaboration. }\end{array}$ \\
\hline $\begin{array}{l}\text { Relying on wide reading to build word } \\
\text { knowledge }\end{array}$ & $\begin{array}{l}\text { Reading a small set of thematically related } \\
\text { texts deeply to build knowledge of words } \\
\text { and concepts }\end{array}$ \\
\hline
\end{tabular}

\section{Figure (2): Shifting how we think about vocabulary instruction.}

Figure (2). Adapted from "Vocabulary learning to enhance reading for understanding" by Lesaux, Nonie k.; and Harris, Julie Russ (2016).. Retrieved from http://www.texasgateway.org/sites/defult/resources/documents/4briefvocabulary.pdf. (retrieved on: 25-6-2017)

Every learner has his own style of learning vocabulary. Amalia $(2009,571)$ identified the following components to develop vocabulary knowledge as follows: "use 'instructional' read-aloud events; provide direct instruction in the meanings of clusters of words and individual 
words; systematically teach students the meaning of prefixes, suffixes, and root words; link spelling instruction to reading and vocabulary instruction; teach the effective, efficient, realistic use of dictionaries, thesauruses, and other reference works; teach, model, and encourage the application of a word-learning strategy; Encourage wide reading; and reate a keen awareness of and a deep interest in language and words".

The study of vocabulary language strategy has been researched in 3 aspects: Metacognitive strategies (planning, monitoring, analyzing, and assessing); Cognitive or mental activities by learners (direct manipulation and transformation); and Social and interactional forms in which learners practice their ability to study new words. (Kudo, 1999, 2). 
Table (1): Vocab-Backup Strategy Description

\begin{tabular}{|c|c|c|c|}
\hline Categories & Strategy & Sub-strategy & Assist learners to... \\
\hline $\begin{array}{l}\text { Cognitive } \\
\text { Strategy }\end{array}$ & $\begin{array}{c}\text { Synonyms } \\
\text { Relations }\end{array}$ & $\begin{array}{l}\text { - Check synonyms first for new words. } \\
\text { - Use semantic map for each word. } \\
\text { - Synonyms mean more words. } \\
\text { - Build up global knowledge of new } \\
\text { words by knowing synonyms. } \\
\text { - Experience different contexts of } \\
\text { new words. }\end{array}$ & $\begin{array}{l}\text { - Expands vocabulary size } \\
\text { in the brain. } \\
\text { - To learn and remember } \\
\text { easier. } \\
\text { - Develop strong } \\
\text { connection for word } \\
\text { relations and usages. }\end{array}$ \\
\hline $\begin{array}{c}\text { Metacognitive } \\
\text { \& Social } \\
\text { Strategies }\end{array}$ & $\begin{array}{c}\text { Learning } \\
\text { definition/s } \\
\text { with } \\
\text { contexts }\end{array}$ & $\begin{array}{l}\text { - Guess the meaning from context } \\
\text { before knowing the meaning. } \\
\text { - Check words' context in } \\
\text { dictionaries. } \\
\text { - Apply different contexts of a word } \\
\text { in speaking \& writing. } \\
\text { - Check the meaning that fits the } \\
\text { new words' context. }\end{array}$ & $\begin{array}{l}\text { - Proper use of the new } \\
\text { words. } \\
\text { - Apply previous } \\
\text { knowledge to guess the } \\
\text { meaning. } \\
\text { - Differentiate specific } \\
\text { contexts of new words. }\end{array}$ \\
\hline $\begin{array}{c}\text { Social } \\
\text { Strategy }\end{array}$ & $\begin{array}{c}\text { Listening \& } \\
\text { Pronunciation } \\
\text { strategy }\end{array}$ & $\begin{array}{l}\text { - Listening is the best practice of all } \\
\text { (people, media, etc). } \\
\text { - Syllable is for sound. } \\
\text { - Private Speech has it all. }\end{array}$ & $\begin{array}{l}\text { - Engage in conversations. } \\
\text { - Enhances listening skills. } \\
\text { - Develop confidence in } \\
\text { speaking skill. } \\
\text { - Improve speaking skill. }\end{array}$ \\
\hline $\begin{array}{c}\text { Metacognitive } \\
\text { Strategy; } \\
\text { Dictionary } \\
\text { Strategies }\end{array}$ & $\begin{array}{c}\text { Bookmark } \\
\text { strategy }\end{array}$ & $\begin{array}{l}\text { - Set up a vocabulary notebook. } \\
\text { - Check new words daily and } \\
\text { weekly. } \\
\text { - Repetition \& retention practices. } \\
\text { - Deliberate vocabulary learning. } \\
\text { - Regularly look up new words in } \\
\text { dictionary. }\end{array}$ & $\begin{array}{l}\text { - Remember new words. } \\
\text { - Evoke memory to use } \\
\text { new words in speaking \& } \\
\text { writing. } \\
\text { - Keep vocabulary learning } \\
\text { updated. } \\
\text { - Endorse both speaking \& } \\
\text { writing skills. } \\
\text { - Enhances long-term } \\
\text { memory practices. }\end{array}$ \\
\hline $\begin{array}{l}\text { Memory } \\
\text { Strategy }\end{array}$ & $\begin{array}{c}\text { Remembering } \\
\text { strategy } \\
\text { for writing }\end{array}$ & $\begin{array}{l}\text { - If I write them, I will keep them in } \\
\text { my mind. } \\
\text { - Picture your word/ visualize new } \\
\text { words. } \\
\text { - Use them in writing. } \\
\text { - Check syllable for spelling } \\
\text { practices. }\end{array}$ & $\begin{array}{l}\text { - Increase writing } \\
\text { comprehension. } \\
\text { - Increase vocabulary size by } \\
\text { visualizing new words. } \\
\text { - Evoke learning } \\
\text { vocabulary by writing. }\end{array}$ \\
\hline
\end{tabular}

Note: table (1) adapted from "Building vocabulary for language learning: Approach for ESL learners to study new vocabulary” by Alhaarbi, Adel M., 2015, Journal of International Students, 5(4), 501-511 
According to Teng $(2015,40)$, vocabulary knowledge includes two dimensions: breadth of vocabulary (vocabulary size, the quantity of words that a learner knows) and depth of vocabulary which refers to the quality of knowing a word (word's meaning, spelling, register, frequency). There are three distinct lines of development in the vocabulary depth: Precision of meaning (the difference between having a limited, vague idea of a word and having much more elaborated and specific knowledge of its meaning); Comprehensive word knowledge (knowledge of semantic, phonological, morphological, syntactic, collocational and pragmatic characteristics of a word); and Network knowledge (the incorporation of the word into lexical network in the mental lexicon with the ability to link it to related words). (Read, 2004, 212)

Based on the studies of Kudo (1999), Mebring (2005), Alharbi (2015), Teng (2015), and Rasouli and Jafari (2016), the following conclusions can be drawn: vocabulary knowledge has become an extremely important part of second language acquisition, and teachers cannot rely on students acquiring the needed vocabulary just through interaction with the language; vocabulary is far beyond merely memorizing but it requires a cohesive set of information including spelling, pronunciation, etc., and using different strategies was correlated positively with breadth and depth of vocabulary.

Pokupec and Njerš (2014) investigated how constructive alignment can be used for vocabulary assessment. The authors administered a questionnaire with 34 teachers of ESP in higher education institutions in Croatia and collected a corpus of used written tests during the academic year 2013 - 2014 in the undergraduate study courses of Business English taught at the Business Economics study program, at Tourism and Hotel Management study program, at the Faculty of Food Technology and Biotechnology and at the Marketing and Communication study program. The results showed that teachers employ an array of methods in teaching 
and assessing vocabulary; however, some of the methods do not encourage deep approach to learning. The discussion is focused on the methods that encourage deep approach to learning and can be aligned with ILOs focusing on relational and functioning knowledge. Finally, this approach is highly advised by the authors, as it not only provides teachers with information on how each of their students is doing, but it also encourages cooperative and deep learning.

\section{Context of the problem}

The researcher who has a 9-year personal experience as an English Language Instructor, noticed that students did not practice strategies required for learning vocabulary. They used to memorize specific words to be adopted in certain topics especially for the sake of the final exam. No time is devoted to teach students how to set the objectives of their vocabulary knowledge, how to brainstorm for constructing and detecting the meaning of new vocabularies or how to revise for the meaning. This point is in agreement with Ahmed's study (2012). Hence, the common focus is on the final product of the work rather than on the process itself. The result is no awareness on the part of the students of the strategies used before, during, and after their own learning of vocabulary.

\section{Statement of the Problem}

The problem of the study is in the weakness of first year students at faculty of engineering vocabulary knowledge. To investigate such a problem, the present study attempts to answer the following question: What is the effectiveness of using "Constructive Alignment" theory for developing English language vocabulary knowledge?

\section{Research Terminology}

\section{Constructive alignment}

It is a design for teaching in which what is intended for students to learn, and how they should express their learning, is clearly stated before teaching takes place. "Constructive" comes from the constructivist 
theory that learners use their own activity to construct their knowledge as interpreted through their own existing schemata. "Alignment" is a principle in curriculum theory that assessment tasks should be aligned to what it is intended to be learned, as in criterion-referenced assessment (Biggs and Tang, 2011, 97)

\section{Vocabulary Knowledge}

From the previous studies, the researcher conducted that the vocabulary knowledge is much more than being able to recall the meaning of a word, but it is the knowledge of word's pronunciation, spelling, frequency, and the author's intended stance of the context features.

\section{Research Methodology}

This study used the quantitative and qualitative methods to explore and investigate the effectiveness of constructive alignment for developing English language vocabulary knowledge.

\section{The Participants of the Study}

The present study utilized the experimental design known as the Pre-Posttest Experimental \& Control Group Design. The participants of the present study were selected from first year students enrolled in Benha Faculty of Engineering during the first semester of the academic year 2016/2017. The study sample $(N=63)$ was divided into two groups: the experimental group $(\mathrm{N}=33)$ and the control group $(\mathrm{N}=30)$ students.

\section{Instruments of the Study}

The vocabulary pre and post tests for first year engineering students were adopted from ILETS academic exams which were related to the students' specialization in order to measure their academic vocabulary skills (Appendix A). 
A vocabulary tests was applied as a pre-test and a post-test. The two tests had two parts: the first one concerns with how the students were able to understand the meanings of the academic vocabularies in the context, and the second part concerns with the ability of the students to utilize the new academic vocabularies in another contexts.

\section{Description of the vocabulary tests.}

The test takes 15 minutes. The pre and the post consisted of two items: first, summary question which indicted two paragraphs and the students had to complete the missing parts with one or two words from the passage they read before. Second, completing a flow chart of a new context in which the students had to use one or two words from a passage they read before.

\section{Validity of the vocabulary tests.}

In order to validate the vocabulary tests, they were submitted to jury members in Curricula and Methods of Teaching English (Appendix A). They were asked to indicate: the suitability of content and the test for the academic level of the students and the clarity of the instructions.

\section{Reliability of the academic reading tests.}

For estimating the reliability of vocabulary tests, inter - rater was used to determine the reliability of the vocabulary tests. To avoid the subjectivity factor in grading the vocabulary tests, it was corrected by three raters: the first was the present study researcher, the second and the third were English Instructors* in Benha Faculty of Education. The Pearson correlation between the scores of the first, the second and the third rater was 0.845 which was statically significant at 0.01 level. So, it can be said that the test was reliable. 
Implementation of the constructive alignment theory

After designing the test and the theory program(")

\begin{tabular}{|c|c|c|c|}
\hline $\mathbf{N}$ & \multicolumn{3}{|c|}{ Sessions of the approach } \\
\hline \multicolumn{2}{|c|}{ Introductory } & \multicolumn{2}{|c|}{$\begin{array}{l}\text { - Identify the constructive alignment theory to vocabulary knowledge. } \\
\text { - Identify the vocabulary strategies of the constructive alignment theory. }\end{array}$} \\
\hline 1 & Session (1) & - Classifying and analyzing information & Summarize and explain activity \\
\hline 2 & Session (2) & $\begin{array}{l}\text { - Using organized words } \\
\text { - Identifying relevant sections }\end{array}$ & Graphic organizer activity \\
\hline 3 & Session (3) & $\begin{array}{l}\text { - Labelling a diagram } \\
\text { - interpreting a figurative language } \\
\text { - Using organized words }\end{array}$ & Concept mapping activity \\
\hline 4 & Session (4) & $\begin{array}{l}\text { - Summarizing with wordlist } \\
\text { - Classifying vocabularies }\end{array}$ & List-group label activity \\
\hline 5 & Session (5) & $\begin{array}{l}\text { - Making word combination and } \\
\text { match the combinations } \\
\text { - Summarizing with wordlist } \\
\text { - Analyzing questions }\end{array}$ & Word analysis activity \\
\hline
\end{tabular}

The experimentation phase was administered as follows:

\section{Pre- asessment}

Before implementing the program, the researcher of the present study applied a pre-test to both the control group and the experimental group on $27^{\text {th }}$ September 2016, to make sure that both groups (experimental and control) are almost equivalent (homogenous). Moreover, the pre-test was used to determine the students' mastery level of the English language vocabulary knowledge. The means, standard deviation and " $t$ " value of the two groups were computed.

Table (2): Findings of " $t$ " test between the control group and the experimental group in the pre-assessment of vocabulary knowledge.

\begin{tabular}{|c|c|c|c|c|c|c|}
\hline Group & $\mathbf{N}$ & Mean & S.D & T-Value & D.F & Sig. \\
\hline \hline Exp. & 33 & 3.3333 & 1.63299 & \multirow{2}{*}{1.416} & \multirow{2}{*}{61} & \multirow{2}{*}{ N.S. } \\
\hline Cont. & 30 & 2.6333 & 2.26645 & & & \\
\hline
\end{tabular}

(*) I. Bassant Sameer and I. Ghade El Sadek: English language instructors in Faculty of Education, Benha University 
Table (2) indicates that there are no significant differences between the mean scores of the two groups on the pre-assessment of the vocabulary knowledge, where " $\mathrm{t}$ " value is (1.416), which is not significant at (0.01) level of significance. This means that the two groups are equivalent in their pre-assessment of the vocabulary knowledge.

\section{Treatment:}

To encourage students to participate in the constructive alignment program, the researcher attracted their interest by telling them that they would learn something new and interesting by using the Internet which is appealed to this generation and by working in groups. At the beginning of each session, the researcher used to set specific, attainable goals related to each part of the constructive alignment program to increase students' motivation and their level of awareness and participation. The most active group was rewarded.

The program was taught to the experimental group students $(n=33)$ by the researcher herself. The program lasted for ten weeks with one session per week and each session lasted for 45 minutes. At the beginning of the sessions, the researcher introduced to the students what they are going to do. First, she told the students about the objectives of the theory and what they are supposed to gain as a result of their participation. After that she told them about the importance of vocabulary knowledge in general and for their academic study and work in particular. At the beginning of each session, she told students the objectives of the session, the researcher's role, the student's role, the instructional materials that will be used, the activities they will perform, and ways of evaluating their progress and making sure that they achieve objectives of the sessions. At the end of the each session the researcher gave students some activities related such as (concept map, list-group label, and word analysis) to what they had learned in order to be sure that they mastered the skills in each session. 


\section{Post-assessment}

After the experimental treatment, the post-test was administered to the participants (experimental \& control groups) on 5th January, 2017.

\section{Findings of the study}

To find out whether there were significant differences in the English vocabulary knowledge between mean scores of the pre-test and the post-test of the study sample, all the data were statistically treated using t-test (Statistical Package for The Social Science SPSS, version 18). Furthermore, to assess the effect size of the treatment, Eta square formula $\left(\mathrm{y}^{2}\right)$ was used. (Abou-Hatab \& Sadek, 2010:441)

After applying the constructive alignment, it was found out that, "There are statistically significant differences between the mean scores of the experimental group and those of the control group students in vocabulary knowledge in the post-test, in favor of the experimental group".

Table (3) presents the student's mean scores, standard deviations, t-value and level of significance of both experimental and control group in the post-test in vocabulary knowledge.

Table (3): Findings of "t-test" between the mean scores of the
experimental group and the control group students in the
post-test in vocabulary knowledge.
\begin{tabular}{|c|c|c|c|c|c|c|}
\hline Group & N & Mean & S.D. & T-Value & D.F. & Sig. \\
\hline Exp. & 33 & 8.2424 & .96922 & 11.943 & 61 & 0.00 \\
\hline Cont. & 30 & 3.2000 & 2.20345 & & & \\
\hline
\end{tabular}

Table (3) shows that there are statistically significant differences between the mean scores of the experimental group and the control group students in vocabulary knowledge in the post-test, in favor of the experimental group, where "t-value" is (11.94) which is significant at the (0.01) level of significance. Thus, the first hypothesis was supported. Moreover, Eta square formula $\left(\mathrm{y}^{2}\right)$ of vocabulary knowledge is 0.70 , so 
the percentage of the effectiveness of constructive alignment theory in developing vocabulary knowledge is $70 \%$.

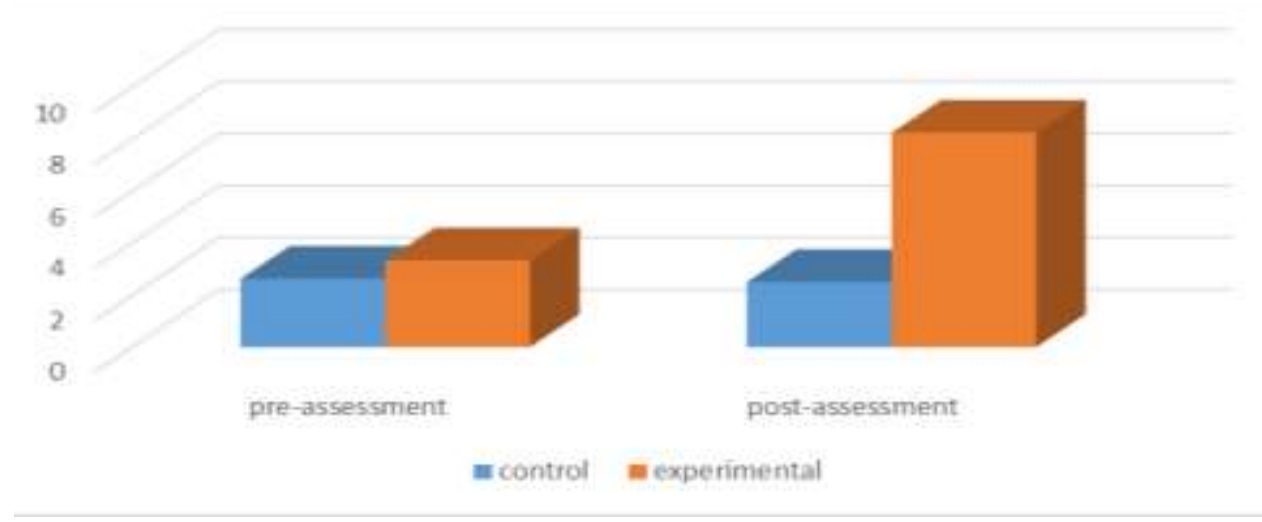

\section{Figure (3):The mean scores of the control group and the experimental group in vocabulary knowledge}

This result may be due to the activities used in the constructive alignment program such as: group work, team work, concept map, listgroup label, and word analysis. These activities helped students to improve their vocabulary knowledge and its performance indicators (guessing meanings of vocabulary items that require cultural information to define; and guessing the meanings of unknown items from context.).

The researcher first modeled these activities in front of the students by using the printed papers and the board that helped students to practice it later. Then she divided the students into small groups and began to practice the previous activities with her guidance. After that students began to apply the activities themselves. Thus, this training helped the students to develop the vocabulary knowledge. Students can comprehend the academic content and make connections between their prior knowledge and the new vocabulary in their academic study. After studying the academic reading passage, they classified the vocabularies and made a chart of its usage, they also made word analysis for the new vocabulary such as prefix and suffix and connected their previous experience with the new vocabularies to construct knowledge and to create meaning schemes which evaluated their progress in vocabulary knowledge. 
This result is consistent with Qian (2002), Rao and et al. (2007), Hermida (2009), Noor (2010), and Chen, and Dhillon (2012).

\section{Conclusion}

Based on the results of the statistical analysis of the data, it can be concluded that the experimental group students' English vocabulary knowledge developed as a result of using "Constructive Alignment" compared with the control group students who were taught through the regular method. This means that "Constructive Alignment" is effective in achieving the aim of the present study.

The effectiveness of the constructive alignment may be due to the various activities and tasks that the researcher presented to the students.

\section{Recommendations of the study}

In the light of the findings, the following recommendations could be presented:

1- Teachers should pay attention to the development of the students' vocabulary knowledge in the secondary stages, because EFL adult learners' academic English vocabulary knowledge problems are better solved out at this stage.

2- Teachers should use the learner-centered approach which helps the learners to control their own learning.

3- Teachers should focus more on group and team work activities that allow students to interact with each other.

4- English language teachers should be trained on the use of constructive alignment steps while teaching English to their students.

5- Teachers should teach students how to use the constructive alignment in academic reading texts in order to develop their vocabulary knowledge through modeling the theory. 
6- Material designers of the subjects have to be cautious about the appropriateness of selected academic texts and the language materials to the students' levels and interests.

7- EFL curriculum designers should pay more attention to extensive reading practice.

\section{Suggestions for Further Research}

The results drawn from this study pointed out a need to conduct further research as follows:

1- Investigating the effectiveness of the constructive alignment to learning in developing learners' performance in the four skills of the English language.

2- Investigating learners' English academic vocabulary knowledge problems and difficulties.

3- Developing remedial programs for solving learners' problems in academic vocabulary knowledge.

4- Investigating the effect of using multimedia and new technologies to promote English academic vocabulary knowledge at different developmental levels. 


\section{References}

Ahmed, N. (2012). The effectiveness of a suggested ESP program in enhancing students' vocabulary building skills, reading comprehension and writing skills at the faculty of agriculture. Unpublished M.A. Thesis, Faculty of Education, Fayoum University, Egypt.

Alharbi, A. (2015). Building vocabulary for language learning: approach for ESL learners to study new vocabulary. Journal of International Students, 5(4), 501-511.

Amalia, S. (2009). Approach to teaching and developing vocabulary. Retrieved from http://steconomica.uoradea.ro/anale/volume/2009/v1-internationalrelations-and-european-ntegration/92.pdf. (retrieved on: 25-6-2017)

Biggs, J. \& Tang, C. (2011). Teaching for quality learning at university: what the student does. Berkshire, England: McGraw-Hill Education.

Biggs, J. (1996) Enhancing teaching through constructive alignment. Higher Education, 32, 347 - 364.

Biggs, J. (2003). Teaching for quality learning at university. The society for Research into Higher Education and Open University Press: Buckingham, U.K.

Chen, L. \& Dhillon, J. K. (2012). Deep approaches to learning in improving reading skills: A case study from Yunnan Agriculture University. Theory and Practice in Language Studies, 2 (8), 1603 $-1613$.

Chua, E. (2013). Constructive alignment VS experiential learning for ESL students. Arab World English Journal, 4(2), 235-245. 
Hermida, J. (2009). The importance of teaching academic reading skills in first-year university course. The International Journal of Research and Review, 3, 20-30.

Jones, C. (2002). Biggs's 3P model of learning: The role of personal characteristics and environmental influences on approaches to learning (Unpublished doctoral thesis). Faculty of Health Science, Griffith University, Australia.

Kudo, Y. (1999). L2 vocabulary learning strategies. Retrieved from http://scolarspace.manoa.hawaii.edu/bitstream/10125/8951/1/NW14. pdf. (retrieved on: 25-6-2017)

Lesaux, N. \& Harris, J. (2016). Vocabulary learning to enhance reading for understanding. Retrieved from http://www.texasgateway.org/sites/defult/resources/documents/4br ief-vocabulary.pdf. (retrieved on: 25-6-2017)

Mebring, J. (2005). Developing vocabulary in second language acquisition: from theories to the classroom. Retrieved from http://www.hpu.edu/CHSS/English/TESOL/ProfessionalDevelopmen t/2006 80TWPfall06/03Mehring.pdf. (retrieved on: 25-6-2017)

Noor, N. (2010). ESL learners' reading approaches of an academic expository text. $3 L$ The Southeast Asian Journal of English Language Studies, 16(2), 19 - 46.

Pokupec, M. \& Njerš, D. (2014). Constructive alignment in assessing vocabulary in business English study courses. Paper presented at The International Language Conference on the Importance of Learning Professional Foreign Languages for Communication between Cultures, Maribor, Slovenia. 
Qian, D. (2002). Investigating the relationship between vocabulary knowledge and academic reading performance: an assessment perspective language learning. A Journal of Research in Language Studies, 52(3), 513- 536.

Rao, Z., Gu, P., Yongqi, Z., Lawrence, J. \& Hu,G. (2007). Approaches to learning and reading strategy use of bilingual primary school pupils. Language Awareness, 16(4), 243 - 262.

Rasouli, F. \& Jafari, K. (2016). A deeper understanding of L2 vocabulary learning and teaching: A review study. International Journal of Language and Linguistics, 4(1), 40- 46.

Read, J. (2004). Plumbing the depth: How should the construct of vocabulary knowledge be defined. In Bogaards, Paul; and Laufer, Batia (Eds.), Vocabulary in a second language (pp. 209-227). Amesterdam, Benjamins Publishing Co. John.

Surgenor, P. (2010) Constructive alignment. Retrieved from http://www.ucd.ie/teaching. (retrieved on: 25-2-2011)

Teng, F. (2015). Assessing the relationship between vocabulary learning strategy use and vocabulary knowledge. PASAA, 49, 39-65.

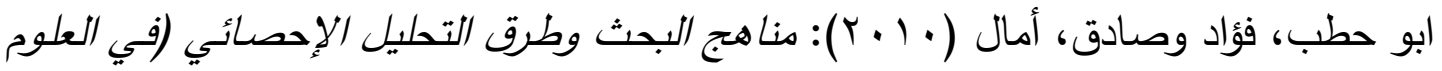
النفسية والتتربوية والإجتماعية). القاهرة: مكتبة الانجلو المصرية. 


\section{Appendix A}

\section{The pre-test}

\section{The first passage:}

\section{PAPER RECYCLING}

(Source: http://www.ielts-mentor.com/reading-sample/academic-reading/34-ieltsacademic-reading-sample-9-paper-recycling)

A) Paper is different from other waste produce because it comes from a sustainable resource: trees. Unlike the minerals and oil used to make plastics and metals, trees are replaceable. Paper is also biodegradable, so it does not pose as much threat to the environment when it is discarded. While 45 out of every 100 tonnes of wood fibre used to make paper in Australia comes from waste paper, the rest comes directly from virgin fibre from forests and plantations. By world standards, this is a good performance since the worldwide average is 33 percent waste paper. Governments have encouraged waste paper collection and sorting schemes and at the same time, the paper industry has responded by developing new recycling technologies that have paved the way for even greater utilization of used fibre. As a result, industry's use of recycled fibres is expected to increase at twice the rate of virgin fibre over the coming years.

B) Already, waste paper constitutes $70 \%$ of paper used for packaging and advances in the technology required to remove ink from the paper have allowed a higher recycled content in newsprint and writing paper. To achieve the benefits of recycling, the community must also contribute. We need to accept a change in the quality of paper products; for example, stationery may be less white and of a rougher texture. There also needs to support from the community for waste paper collection programs. Not only do we need to make the paper available to collectors but it also needs to be separated into different types and sorted from contaminants such as staples, paperclips, string and other miscellaneous items. 
C) There are technical limitations to the amount of paper which can be recycled and some paper products cannot be collected for re-use. These include paper in the form of books and permanent records, photographic paper and paper which is badly contaminated. The four most common sources of paper for recycling are factories and retail stores which gather large amounts of packaging material in which goods are delivered, also offices which have unwanted business documents and computer output, paper converters and printers and lastly households which discard newspapers and packaging material. The paper manufacturer pays a price for the paper and may also incur the collection cost.

D) Once collected, the paper has to be sorted by hand by people trained to recognise various types of paper. This is necessary because some types of paper can only be made from particular kinds of recycled fibre. The sorted paper then has to be repulped or mixed with water and broken down into its individual fibres. This mixture is called stock and may contain a wide variety of contaminating materials, particularly if it is made from mixed waste paper which has had little sorting. Various machineries are used to remove other materials from the stock. After passing through the repulping process, the fibres from printed waste paper are grey in colour because the printing ink has soaked into the individual fibres. This recycled material can only be used in products where the grey colour does not matter, such as cardboard boxes but if the grey colour is not acceptable, the fibres must be de-inked. This involves adding chemicals such as caustic soda or other alkalis, soaps and detergents, water-hardening agents such as calcium chloride, frothing agents and bleaching agents. Before the recycled fibres can be made into paper they must be refined or treated in such a way that they bond together. 
E) Most paper products must contain some virgin fibre as well as recycled fibres and unlike glass, paper cannot be recycled indefinitely. Most paper is down-cycled which means that a product made from recycled paper is of an inferior quality to the original paper. Recycling paper is beneficial in that it saves some of the energy, labour and capital that go into producing virgin pulp. However, recycling requires the use of fossil fuel, a non-renewable energy source, to collect the waste paper from the community and to process it to produce new paper. And the recycling process still creates emissions which require treatment before they can be disposed of safely. Nevertheless, paper recycling is an important economical and environmental practice but one which must be carried out in a rational and viable manner for it to be useful to both industry and the community.

\section{Questions 1-7}

Complete the summary below of the first two paragraphs of the Reading Passage.

Choose ONE OR TWO WORDS from the Reading Passage for each answer.

Write your answers in boxes 30-36 on your answer sheet.

\section{SUMMARY}

\section{Example ....}

From the point of view of recycling, paper has two advantages over minerals and ............oil........... in that firstly it comes from a resource which is ........ (1) ........ and secondly, it is less threatening to our environment when we throw it away because it is ....... (2) ...... Although Australia's record in the re-use of waste paper is good, it is still necessary to use a combination of recycled fibre and ......... (3) ......... to make new paper. The paper industry has contributed positively and people have also been encouraged by ..........(4) .......... to collect their 
waste on a regular basis. One major difficulty is the removal of ink from used paper but .......... (5) .......... are being made in this area. However, we need to learn to accept paper which is generally of a lower .......... (6) .......... than before and to sort our waste paper by removing .......... (7) ........ before discarding it for collection.

Look at paragraphs $\mathrm{C}, \mathrm{D}$, and $\mathrm{E}$ and, using the information in the passage, complete the flow chart below. Write your answers in boxes 8-12 on your answer sheet. Use ONE OR TWO WORDS for each answer.

- Waste Paper collected from: Factories, Retail stores, ...(8)..., Paper converted and printers, Households.

- The Paper is then .....(9).... and ....(10)....by adding water. Chemicals are added in order to ....(11)... The fibers are then ...(12).....

\section{The second passage:}

\section{AIRPORTS ON WATER}

(Source: http://www.ielts-mentor.com/reading-sample/academic-reading/794-ieltsacademic-reading-sample-124-airports-on-water)

River deltas are difficult places for map makers. The river builds them up, the sea wears them down; their outlines are always changing. The changes in China's Pearl River delta, however, are more dramatic than these natural fluctuations. An island six kilometers long and with a total area of 1248 hectares is being created there. And the civil engineers are as interested in performance as in speed and size. This is a bit of the delta that they want to endure.

The new island of Chek Lap Kok, the site of Hong Kong's new airport, is $83 \%$ complete. The giant dumper trucks rumbling across it will have finished their job by the middle of this year and the airport itself will be built at a similarly breakneck pace.

\section{9}


As Chek Lap Kok rises, however, another new Asian island is sinking back into the sea. This is a 520-hectare island built in Osaka Bay, Japan, that serves as the platform for the new Kansai airport. Chek Lap Kok was built in a different way, and thus hopes to avoid the same sinking fate.

The usual way to reclaim land is to pile sand rock on to the seabed. When the seabed oozes with mud, this is rather like placing a textbook on a wet sponge: the weight squeezes the water out, causing both water and sponge to settle lower. The settlement is rarely even: different parts sink at different rates. So buildings, pipes, roads and so on tend to buckle and crack. You can engineer around these problems, or you can engineer them out. Kansai took the first approach; Chek Lap Kok is taking the second.

The differences are both political and geological. Kansai was supposed to be built just one kilometer offshore, where the seabed is quite solid. Fishermen protested, and the site was shifted a further five kilometers. That put it in deeper water (around 20 meters) and above a seabed that consisted of 20 meters of soft alluvial silt and mud deposits. Worse, below it was a not-very- firm glacial deposit hundreds of meters thick.

The Kansai builders recognized that settlement was inevitable. Sand was driven into the seabed to strengthen it before the landfill was piled on top, in an attempt to slow the process; but this has not been as effective as had been hoped. To cope with settlement, Kansai's giant terminal is supported on 900 pillars. Each of them can be individually jacked up, allowing wedges to be added underneath. That is meant to keep the building level. But it could be a tricky task.

Conditions are different at Chek Lap Kok. There was some land there to begin with, the original little island of Chek Lap Kok and a smaller outcrop called Lam Chau. Between them, these two outcrops of hard, weathered granite make up a quarter of the new island's surface 
area. Unfortunately, between the islands there was a layer of soft mud, 27 meters thick in places.

According to Frans Uiterwijk, a Dutchman who is the project's reclamation director, it would have been possible to leave this mud below the reclaimed land, and to deal with the resulting settlement by the Kansai method. But the consortium that won the contract for the island opted for a more aggressive approach. It assembled the worlds largest fleet of dredgers, which sucked up $150 \mathrm{~m}$ cubic meters of clay and mud and dumped it in deeper waters. At the same time, sand was dredged from the waters and piled on top of the layer of stiff clay that the massive dredging had laid bare.

Nor was the sand the only thing used. The original granite island which had hills up to 120 meters high was drilled and blasted into boulders no bigger than two meters in diameter. This provided $70 \mathrm{~m}$ cubic meters of granite to add to the island's foundations. Because the heap of boulders does not fill the space perfectly, this represents the equivalent of $105 \mathrm{~m}$ cubic meters of landfill. Most of the rock will become the foundations for the airport's runways and its taxiways. The sand dredged from the waters will also be used to provide a two-meter capping layer over the granite platform. This makes it easier for utilities to dig trenches -granite is unyielding stuff. Most of the terminal buildings will be placed above the site of the existing island. Only a limited amount of pile-driving is needed to support building foundations above softer areas.

The completed island will be six to seven meters above sea level. In all, $350 \mathrm{~m}$ cubic meters of material will have been moved. And much of it, like the overloads, has to be moved several times before reaching its final resting place. For example, there has to be a motorway capable of carrying 150-tonne dump-trucks; and there has to be a raised area for 
the 15,000 construction workers. These are temporary; they will be removed when the airport is finished.

The airport, though, is here to stay. To protect it, the new coastline is being bolstered with a formidable twelve kilometers of sea defenses. The brunt of a typhoon will be deflected by the neighboring island of Lantau; the sea walls should guard against the rest. Gentler but more persistent bad weather - the downpours of the summer monsoon - is also being taken into account. A mat-like material called geo textile is being laid across the island to separate the rock and sand layers. That will stop sand particles from being washed into the rock voids, and so causing further settlement This island is being built never to be sunk.

\section{Questions 10-13}

\section{Complete the summary below.}

Choose your answers from the box below the summary and write them in boxes 10-13 on your answer sheet.

NB There are more words than spaces, so you will not use them all.

When the new Chek Lap Kok airport has been completed, the raised area and the ( Example) will be removed. motorway

The island will be partially protected from storms by (10) and also by (11) Further settlement caused by (12) will be prevented by the use of $.(13) \ldots \ldots . . . .$.

[construction workers - coastline - dump-trucks - geotextile - Lantau Island - motorway - rainfall - rock and sand - rock voids - sea walls typhoons] 


\section{The post-test}

\section{CREATING ARTIFICIAL REEFS}

(Source: $\quad$ http://www.ielts-mentor.com/reading-sample/academic-reading/44-ieltsacademic-reading-sample-19-creating-artificial-reefs)

In the coastal waters of the US, a nation's leftovers have been discarded. Derelict ships, concrete blocks, scrapped cars, army tanks, tyres filled with concrete and redundant planes litter the sea floor. However, this is not waste disposal, but part of a coordinated, state-run programme. To recently arrived fish, plants and other sea organisms, these artificial reefs are an ideal home, offering food and shelter.

Sea-dumping incites widespread condemnation. Little surprise when oceans are seen as 'convenient' dumping grounds for the rubbish we have created but would rather forget. However, scientific evidence suggests that if we dump the right things, sea life can actually be enhanced. And more recently, purpose-built structures of steel or concrete have been employed - some the size of small apartment blocks principally to increase fish harvests.

Strong currents, for example, the choice of design and materials for an artificial reef depends on where it is going to be placed. In areas of a solid concrete structure will be more appropriate than ballasted tyres. It also depends on what species are to be attracted. It is pointless creating high-rise structures for fish that prefer flat or low-relief habitat. But the most important consideration is the purpose of the reef.

In the US, where there is a national reef plan using cleaned up rigs and tanks, artificial reefs have mainly been used to attract fish for recreational fishing or sport-diving. But there are many other ways in which they can be used to manage the marine habitat. For as well as protecting existing habitat, providing purpose-built accommodation for 
commercial species (such as lobsters and octupi) and acting as sea defences, they can be an effective way of improving fish harvests.

Japan, for example, has created vast areas of artificial habitat rather than isolated reefs - to increase its fish stocks. In fact, the cultural and historical importance of seafood in Japan is reflected by the fact that it is a world leader in reef technology; what's more, those who construct and deploy reefs have sole rights to the harvest.

In Europe, artificial reefs have been mainly employed to protect habitat. Particularly so in the Mediterranean where reefs have been sunk as physical obstacles to stop illegal trawling, which is destroying sea grass beds and the marine life that depends on them. If you want to protect areas of the seabed, you need something that will stop trawlers dead in their tracks,' says Dr Antony Jensen of the Southampton Oceanography Centre.

Italy boasts considerable artificial reef activity. It deployed its first scientifically planned reef using concrete cubes assembled in pyramid forms in 1974 to enhance fisheries and stop trawling. And Spain has built nearly 50 reefs in its waters, mainly to discourage trawling and enhance the productivity of fisheries. Meanwhile, Britain established its first quarried rock artificial reef in 1984 off the Scottish coast, to assess its potential for attracting commercial species.

But while the scientific study of these structures is a little over a quarter of a century old, artificial reefs made out of readily available materials such as bamboo and coconuts have been used by fishermen for centuries. And the benefits have been enormous. By placing reefs close to home, fishermen can save time and fuel. But unless they are carefully managed, these areas can become over- fished. In the Philippines, for example, where artificial reef programmes have been instigated in response to declining fish populations, catches are often allowed to 
exceed the maximum potential new production of the artificial reef because there is no proper management control.

There is no doubt that artificial reefs have lots to offer. And while purpose-built structures are effective, the real challenge now is to develop environmentally safe ways of using recycled waste to increase marine diversity. This will require more scientific research. For example, the leachates from one of the most commonly used reef materials, tyres, could potentially be harmful to the creatures and plants that they are supposed to attract. Yet few extensive studies have been undertaken into the long- term effects of disposing of tyres at sea. And at the moment, there is little consensus about what is environmentally acceptable to dump at sea, especially when it comes to oil and gas rigs. Clearly, the challenge is to develop environmentally acceptable ways of disposing of our rubbish while enhancing marine life too. What we must never be allowed to do is have an excuse for dumping anything we like at sea.

\section{Questions 4-8}

Complete the table below. Choose NO MORE THAN THREE WORDS from the passage for each answer. Write your answers in boxes 4-8 on your answer sheet.

\begin{tabular}{|c|l|l||}
\hline Area/Country & \multicolumn{1}{|c|}{ Type of Reef } & \multicolumn{1}{|c|}{ Purpose } \\
\hline \hline US & Made using old ....(4).... & $\begin{array}{l}\text { To attract fish for leisure } \\
\text { activities }\end{array}$ \\
\hline Japan & $\begin{array}{l}\text { Forms large area of artificial } \\
\text { habitat }\end{array}$ & to improve ....(5).... \\
\hline Europe & lies deep down to form ...(6).... & to act as a sea defence \\
\hline Italy & $\begin{array}{l}\text { Consists of pyramid shapes } \\
\text { of ....(7).... }\end{array}$ & to prevent trawling \\
\hline Britain & made of rock & $\begin{array}{l}\text { to encourage ....(8).... Fish } \\
\text { species }\end{array}$ \\
\hline
\end{tabular}




\section{Questions 9-12}

Using NO MORE THAN THREE WORDS, complete the following sentences. Write your answers in boxes 9-12 on your answer sheet.

In .....(9)......, people who build reefs are legally entitled to all the fish they attract. Trawling inhibits the development of marine life because it damages the .....(10)...... In the past, both .......(11).......were used to make reefs. To ensure that reefs are not over-fished, good ......(12)..... is required.

\section{Appendix B}

The List of Jury

\begin{tabular}{||l|c|}
\hline \multicolumn{1}{||c|}{ Name } & Job \\
\hline \hline Dr. Ahmed Seif & $\begin{array}{c}\text { Professor of (TEFL) } \\
\text { Faculty of Education, Menofia University }\end{array}$ \\
\hline Dr. Mohamed Hassan Ibrahim & $\begin{array}{c}\text { Professor of (TEFL) } \\
\text { Faculty of Education, Zagazig University }\end{array}$ \\
\hline Dr. Nahed Mohamed Mahmoud & $\begin{array}{c}\text { Assistant Professor of (TEFL) } \\
\text { Faculty of Education, Menofia University }\end{array}$ \\
\hline Dr. Micheal Abd Elmesseh Awad & $\begin{array}{c}\text { Assistant Professor of (TEFL) } \\
\text { Faculty of Education, Zagazig University }\end{array}$ \\
\hline Dr. Ahmed Abdel Salam Edries & $\begin{array}{c}\text { Lecturer of (TEFL) } \\
\text { Faculty of Education, Zagazig University }\end{array}$ \\
\hline
\end{tabular}

